\title{
Macro, Meso, and Micro Policies for Strengthening Entrepreneurship: Towards an Integrated Competitiveness Policy
}

\author{
Charis Vlados \\ Department of Economics, Democritus University of Thrace \\ PO Box 69100, Panepistimioupoli, Komotini, Greece \\ School of Business, University of Nicosia \\ PO Box 24005, CY-1700, 46 Makedonitissas Avenue, CY-2417, Nicosia \\ Cyprus \\ Dimos Chatzinikolaou \\ Department of Economics, Democritus University of Thrace \\ PO Box 69100, Panepistimioupoli, Komotini, Greece
}

\begin{abstract}
This article aims to propose an integrated policy framework for competitiveness and entrepreneurship at a unified macro-meso-micro level. The article presents the evolution of the definition of competitiveness and competitiveness policy and focuses next on modern definitions of macro-policies, meso-policies, and micro-policies by presenting their conceptual synthesis based on the literature. Then, by building on the approach of "competitiveness web," it presents the implications that such an overarching concept can have on the micro-meso-macro level of entrepreneurship strengthening policies. In this context, it leverages the "Stra.Tech.Man" approach to entrepreneurship dynamics, which implies that business innovation derives from the synthesis of the innate spheres of strategy, technology, and management. At the same time, it proposes the micro-meso-level policy of "Local Development and Innovation Institutes" in the overall context of the competitiveness web. The proposed "competitiveness web" policy framework can address the issue of fostering entrepreneurship in today's environment of globalization because it takes into account all the building blocks of socio-economic systems by describing the general framework of the policies at the micro-meso-macro socioeconomic levels.
\end{abstract}

Keywords: Competitiveness policy, entrepreneurship policy, socio-economic development, micro-meso-macro, competitiveness web, Stra.Tech.Man approach, Institutes of Local Development and Innovation.

\section{Introduction}

One of the most critical issues of development of the different socio-economic systems is their level of competitiveness. The first discussions on the competitiveness of nations began around the late 1980s as aftereffect of the rapid growth of the Japanese industry that caused back then justified fears in the U.S. and Europe over the maintenance of their international market shares and the apparent loss of leadership in geo-economic and technological terms (Kim, 2019; Ohmae, 1985). In the years that followed, the scientific debate went through various phases of development, contestation, and redefinition until the beginning of the $21^{\text {st }}$ century. In particular, however, after the outbreak of the global crisis in 2008-9, it seems to acquire a new conceptual outline and interest.

To this end, a new division within the scientific community on the subject seems to emerge. On the one hand, some analysts focus on particularly positive prospects due to the rapid diffusion of new technologies (Aghion et al., 2007), while on the other hand, several economists note that the export performance indicators of most developed countries seem to be quite problematic after overcoming the shock of 2008-9 (Bricongne et al., 2012). Others insist on a more profound restructuring process of globalization that redefines completely the status quo that concerns how all nations compete on a global scale now. This process paves the way for a "new globalization" (Vlados, Deniozos, \& Chatzinikolaou, 2018).

In these circumstances, to strengthen the entrepreneurship in different socio-economic systems seems to be one of the most important priorities of economic policy (Gaudens-Omer, 2018; Kao \& Hung, 2015). From a macroeconomic perspective, promoting an institutional framework conducive to entrepreneurship development seems to take on a prominent role in academic debate and political practice over time (Khattab \& Al-Magli, 2017). 
Entrepreneurship policies, in particular, are directly linked to socio-economic development as they have a "horizontal" (macro-level) objective of safeguarding the freedom of trade and property rights (Dutz et al., 2000). At the same time, as a "vertical" target (micro-level), they focus on the individual's ability to integrate change and innovation into the business endeavor (Link, 2007). In this context, entrepreneurship policy could connect companies with specialized stakeholders and knowledge diffusion agents that can enhance the firm's developmental prospects, and provide training, education, mentoring, and consulting services. It can also directly intervene in new innovative endeavors (Autio, 2016).

A common distinction between micro and macro policies is between horizontal or vertical policies. According to Warwick (2013), horizontal policies correspond to practices fostering the business environment while selective-vertical policies may aim to promote specific policy skills for specific firms, usually in specific sectors and spaces (meso-level). Governments today seem to prefer horizontal or integrated policies, as the objectives they seek to achieve are complex and involve multiple levels of authority (Torjman, 2005). In today's complex global environment, where "interactive" governmental approaches come to the fore, and where different government bodies can transfer and exchange knowledge and skills, the distinction between vertical and horizontal policies can involve the distinction of "diagonal" policies (Torfing et al., 2012). In the "diagonal" orientation of economic policy, different levels of a government communicate with dynamic processes, giving and receiving flows from different policy areas.

In the current restructuring of globalization, the analytical focus of development and underdevelopment seems to be on the promotion of integrated innovation (and hence the broader objective of competitiveness), especially at the microlevel of the firm (Vlados, 2019c). In contemporary economic crises (Andreou et al., 2017; Andrikopoulos \& Nastopoulos, 2015), macroeconomic regulations appear to have a dominant role, leading to a conflict between the interests pursued by macroeconomic and microeconomic policies (Danielsson, 2015).

Undoubtedly, liberal policies to promote international trade through entrepreneurship are imperative nowadays but have to be accompanied by prudent macroeconomic management and micro-level policies that enhance domestic competitiveness (Kappel \& Ghani, 2003). Several studies show that the competitiveness of socio-economic systems at the sectoral or national level is the primary concern (Ismail \& Khalek, 2018). However, how valid is such a "restrictive" approach to competitiveness?

According to these introductory remarks, it seems essential to explore specific questions related to the level of conceptual and practical development of policies to strengthen entrepreneurship and competitiveness in our days. In this regard, the way literature and policy practice address the distinction between micro, meso, and macro policies and how they relate to each other can be a focal point of research. Variations in the weight attributed at each level of analysis to enhance entrepreneurship potential exist and, therefore, such analysis could clarify the prevailing perceptions over time. Therefore, an integrated approach to the policies strengthening entrepreneurship in macro, meso, and micro terms, simultaneously and in a new way of synthesis, would probably be possible and beneficial.

\section{Methodology and structure}

This article aims to identify an integrated concept of competitiveness policy that can strengthen entrepreneurship potential in different spatial levels. It involves the following methodological steps:

I. Firstly, once it defines the concept of competitiveness, it explores how policies of competitiveness enhancement evolve and identify their current level of development and their principal targets.

II. Second, it identifies how recent theory addresses policies at the macro, meso, and micro levels, moving forward with a critical assessment by presenting approaches that are more integrated and comprehensive.

III. In this context, it seeks a new perspective on the phenomenon of competitiveness in the form of a systemic "competitiveness web" that takes into account the integration of different micro-meso-macro levels through dynamic processes. After placing the focus of competitiveness/entrepreneurship policy on the dynamics of the firm, it uses the competitiveness web as an integrated policy framework. At the same time, it builds on the microdynamics of the firm in terms of strategy-technology-management (Stra.Tech.Man approach) and the micro-meso level policy proposal of the Local Development and Innovation Institutes (ILDI) mechanism. The ILDI prioritizes the diagnosis of the firms' Stra.Tech.Man innovative potential and, therefore, the intervention for strengthening the competitiveness of the local socio-economic system.

IV. Finally, it proceeds with an overview of the results and re-examines the proposed conceptual framework.

\section{Policies to enhance competitiveness: Past, present, and future trends}

To find out the content of competitiveness policies, it seems essential to define the evolving concept of competitiveness, as understood by the literature and part of policymakers. 
To this end, the research by Aiginger et al. (2013) provides a useful sample of definitions of competitiveness over the past four decades (Table 1):

Table 1: Definitions of competitiveness, based on Aiginger et al. (2013)

\begin{tabular}{|c|c|}
\hline $\begin{array}{l}\text { Scott and Lodge } \\
(1985)\end{array}$ & $\begin{array}{l}\text { "... a nation state's ability to produce, distribute and service goods in the } \\
\text { international economy ... and to do so in a way that earns a rising standard } \\
\text { of living." }\end{array}$ \\
\hline Fagerberg (1988) & $\begin{array}{l}\text { "... the ability of a country to realize central economic policy goals, } \\
\text { especially growth in income and employment, without running into balance } \\
\text { of payment difficulties." }\end{array}$ \\
\hline Porter (1990) & $\begin{array}{l}\text { "The only meaningful concept of competitiveness at the national level is } \\
\text { national productivity." }\end{array}$ \\
\hline 994) & $\begin{array}{l}\text { "World competitiveness is the ability of a country or a company to, } \\
\text { proportionally, generate more wealth than its competitors in the world } \\
\text { markets." }\end{array}$ \\
\hline OECD (1995) & $\begin{array}{l}\text { "... the ability of companies, industries, regions, nations or supra-national } \\
\text { regions to generate, while being and remaining opened to international } \\
\text { competition, relatively high factor income and factor employment levels." }\end{array}$ \\
\hline $\begin{array}{l}\text { World Economic } \\
\text { Forum }(2000)\end{array}$ & $\begin{array}{l}\text { "Competitiveness is the set of institutions and economic policies supportive } \\
\text { of high rates of economic growth in the medium term." }\end{array}$ \\
\hline $\begin{array}{l}\text { European } \\
\text { Commission } \\
(2011)\end{array}$ & $\begin{array}{l}\text { "Ultimately, competitiveness is about stepping up productivity, as this is the } \\
\text { only way to achieve sustained growth in per capita income - which in turn } \\
\text { raises living standards." }\end{array}$ \\
\hline $\begin{array}{ll}\text { Janger } & \text { et } \\
(2011) & \end{array}$ & $\begin{array}{l}\text { "... define competitiveness as the ability to raise standards of living and } \\
\text { employment, while maintaining a sustainable environment and sustainable } \\
\text { external balances." }\end{array}$ \\
\hline
\end{tabular}

The notion of competitiveness transforms over time from seeking exclusively national and international determinants towards more advanced and specific forms. For example, competitiveness nowadays refers to firms as well as to sectors and spatial entities. The literature even embraces complex concepts such as sustainable development and the natural environment, while the conceptualization of competitiveness as equal to productivity seems a declining scientific perspective (Krugman, 1994).

From a historical point of view, the goal of national competitiveness has been around for several years, though not explicitly. Hamilton's Report on the Subject of Manufactures in 1791 (Irwin, 2004), which introduced the hypothesis of "infant industries" and the need to support them is one such early endeavor. Until the mid-1970s, national economies were mostly self-contained with a relatively limited volume of international trade, and so the focus on competitiveness was practically small (Atkinson, 2017). At that time, industrial production was necessary for the growth of the economy while market failures were a condition to avoid and intervene, and, as a result, the policy had to aim at protecting "infant industries" (Hirschman, 1958; Rosenstein-Rodan, 1943).

From the rise of globalization (Levitt, 1983), the debate about seeking and enhancing competitiveness comes to the fore. The facilitating of communications worldwide and the gradual disengagement from the fixed exchange rate system established at Bretton Woods create massive international flows, and national economies become vulnerable to international disruptions (Berry et al., 2016). As a result, governments find it increasingly difficult to pick specific firms or regions as the new winners (Schultze, 1983). Industrial policy starts to focus on the liberalization of markets and attracting foreign direct investment, aided by macroeconomic stability and minimal government intervention (Baldwin, 1969; Pack, 2000).

At the same time, one point of agreement among economists who studied the success factors of development strategies called "externally oriented," and in particular those of Southeast Asian countries during the $20^{\text {th }}$ century, is the recognition of the vital role played by the government's active intervention in strengthening the competitiveness of each country, more or less developed (Shen, 1991). Today, mainly since 2000, competitiveness policy becomes more explicit (Corrales-Leal, 2006). In addition to promoting the competitiveness of different globalized sectors (Lall, 2004), it seeks to ensure the continual development of the national economy. Although some nations (Schwab \& Sala-iMartín, 2017), regions (Dijkstra et al., 2017), or firms become the losers in today's game of competitiveness, competitiveness policies aimed at promoting skills and innovational capacity in the micro-level of the firm spillover positively throughout the socio-economic system (Froy, 2013). 
In this context, flexibility and pro-active approach in policy articulation are necessary (Naudé, 2010), which can create a framework aimed at developing the socio-economic system at all levels (Peneder, 2017).

\section{Contemporary policy articulation at macro, meso, and micro levels}

These new policies of enhancing competitiveness often take on a character and political orientation at the basis of the level at which they aim to incorporate their intervention. In social sciences, the articulation of microeconomic, macroeconomic, and macro-social level constitutes a challenging issue (Serpa \& Ferreira, 2019; Wiley, 1988). The meso-level analysis, which refers to the aggregations of one or more networks and organizations, is the conceptual connection between the micro-macro analytical levels (Dopfer, 2011).

In the macro dimension and macro-policy orientation, Hoogduin et al. (2011) argue that macro-policy interactions are usually confined to debt management and monetary and fiscal policies while adding to their analysis the concept of financial stability. Therefore, the macroeconomic policy relates mainly to those issues that usually a country's "Ministry of Finance" undertakes by intending to secure specific macroeconomic indicators. Table 2 provides additional definitions of macro policy (Table 2):

Table 2: Macro-policies definitions

\begin{tabular}{|l|l|l|}
\hline $\begin{array}{l}\text { Timmer } \\
(2000, \\
285)\end{array}$ & p. & $\begin{array}{l}\text { "The rate and distribution of economic growth are primarily matters of macroeconomic } \\
\text { and trade policy (once asset distributions are given as an initial condition)." }\end{array}$ \\
\hline $\begin{array}{l}\text { Hartwell } \\
(2014, \quad \text { p. } \\
434)\end{array}$ & $\begin{array}{l}\text { "... macroeconomic policies, put in place to influence predominantly macroeconomic } \\
\text { aggregates, may have counterproductive or deleterious effects on firm creation via direct } \\
\text { costs or via second-order effects such as volatility or hampering expectation formation." }\end{array}$ \\
\hline $\begin{array}{l}\text { Ahluwalia } \\
(2015, \text { p. } 6)\end{array}$ & $\begin{array}{l}\text { "Policy analysis at the macro-level is usually based on a set of quantitative projections } \\
\text { of how the economy is likely to evolve in the short to medium term, taking into account } \\
\text { the likely developments in the world economy and domestic constraints. These } \\
\text { projections are usually based on some formal macroeconomic models but a great deal of } \\
\text { judgment is also used to modify model results." }\end{array}$ \\
\hline
\end{tabular}

The macroeconomic policy usually affects macroeconomic sizes by using forecasts on the short-to-medium term projected evolution of the national economy. In the traditional macroeconomic context, the extent and diffusion of economic growth is a priority, and in this way, in the absence of the factors contributing to economic growth, the overall economy can move backward in developmental terms when it does not emphasize properly on the overall organic ingredients (firms, sectors, spaces, institutions, and natural equilibrium) of the socio-economic system. In this sense, macroeconomic growth is the quantitative change of some indicators in the short or medium term, while macrosocioeconomic development is the ability of a socio-economic system to increase its product over time in "totalizing" qualitative terms (Perroux, 1969).

At the meso dimension and meso-policy field of analysis, one of the main features is selectiveness. Levin (2018) argues that meso-policies target specific regulations, laws, and standards of compliance based on specific regions, sectors, and patterns of behavior. In this sense, meso-policy constitutes an intermediate approach, geared towards specific subsystems. Table 3 presents additional meso-policy definitions:

Table 3: Meso-policies definitions

\begin{tabular}{|l|l|}
\hline $\begin{array}{l}\text { Sedelmeier } \\
(2002, \text { pp. 627- } \\
628)\end{array}$ & "meso dimension'-substantive policy outcomes in distinctive sectoral policy areas" \\
\hline $\begin{array}{l}\text { Meyer-Stamer } \\
(2005, \mathrm{pp} .7-8)\end{array}$ & $\begin{array}{l}\text { "The defining criterion for a mesopolicy is its selectivity. Fiscal policy, monetary policy, exchange } \\
\text { rate policy and trade policy are generic policies. They affect all economic actors in the same way, } \\
\text { and they are thus elements of the macrolevel. Mesopolicies, by contrast, are selective. They } \\
\text { specifically target limited groups of economic actors. Typical examples are technology policy } \\
\text { (aiming selectively at innovative companies or sectors) and regional policy (selectively promoting } \\
\text { lagging regions and the economic actors that happen to be based there)." }\end{array}$ \\
\hline $\begin{array}{l}\text { Marra et al. } \\
(2018, \text { p. 801) }\end{array}$ & $\begin{array}{l}\text { "Circular economy implementation at the meso level concerns inter-firm initiatives-i.e. practices } \\
\text { regarding the creation and maintenance of symbiotic relationships between firms and eco-industrial } \\
\text { networks, where firms are able to utilize industrial by-products such as heat energy, wastewater and } \\
\text { manufacturing waste." }\end{array}$ \\
\hline
\end{tabular}


Meso-policy is selective and focuses on specific areas of socio-economic interest. Contemporary meso-competitiveness policies (as opposed to general macro-level policies) appear to aim at innovative firms or sectors and specific regions. At the level of sustainable development, the meso-level concerns networks between symbiotic firms and business ecosystems (Acs et al., 2017). More generally, the meso-level of a socio-economic system studies the dynamic interactions between firms (micro-level) and macro factors that host their actions.

In the micro dimension of policy, the main issue is to support different socio-economic actors by increasing their productivity. In this context, fostering entrepreneurship potential and all other factors related to business competitiveness is a priority for new micro policies (OECD, 2005). Table 4 presents a sample of conceptualization in the micro-policies field of analysis:

\section{Table 4: Micro-policies definitions}

\begin{tabular}{|c|c|}
\hline $\begin{array}{l}\text { Bianchi } \quad(2000, \\
\text { p. 327) }\end{array}$ & $\begin{array}{l}\text { "The micro level establishes the capabilities with which the actors take part in the economic arena, } \\
\text { which means that micro policies not only include local firms, but also local educational institutions, } \\
\text { infrastructures, etc. Together policies on both levels, macro and micro, must be integrated to create } \\
\text { the positive externalities needed for growth in order to avoid the formation of groups resistant to } \\
\text { change." }\end{array}$ \\
\hline $\begin{array}{l}\text { OECD } \\
\text { pp. 5-6) }\end{array}$ & $\begin{array}{l}\text { "• Fostering firm creation and entrepreneurship: increasing the quality and relevance of } \\
\text { educational attainment; providing incentives for continuous training/lifelong learning; fostering } \\
\text { knowledge-based management and organization in enterprises. } \\
\text { - Seizing the benefits of information and communications technology (ICT): Developing ICT skills; } \\
\text { stimulating competition in communication markets; implementing e-government; developing digital } \\
\text { content. } \\
\text { - Exploiting and diffusing science and technology: Enhancing the quality of public research; } \\
\text { promoting industry-science links; stimulating demand for new products, processes and services. } \\
\text { - Enhancing human capital and realizing its potential: Increasing access to venture capital; } \\
\text { ensuring efficient bankruptcy regimes; providing entrepreneurial education." }\end{array}$ \\
\hline $\begin{array}{l}\text { Fotopoulos and } \\
\text { Storey (2019, p. } \\
192)\end{array}$ & $\begin{array}{l}\text { "Micro policies, in contrast, focus upon providing support, either for groups or for individuals, in } \\
\text { order to address business-related problems or social concerns. Some individuals or groups, for } \\
\text { example, may be entrepreneurially disadvantaged due to unemployment, by where they live, or by } \\
\text { their ethnicity, age, gender or disability, so preventing them from starting or growing a business. } \\
\text { For these groups, governments in many countries have programs that provide advice, training, } \\
\text { funding or some combination of all three." }\end{array}$ \\
\hline
\end{tabular}

These developments in the literature imply that new micro-level policies aim at strengthening the entrepreneurship capacities of the specific socio-economic subsystems, with the primary tools being education, training, funding, research, and all other factors that can boost the competitiveness of the specific actor. Micro policies focus primarily on the general fostering of entrepreneurship, the promotion of science and technology within firms, and the enhancement of human, intellectual, and social capital in the targeted socio-economic space.

Overall, it seems that policies at the macro, meso, and micro levels are mostly unrelated to each other in the literature until these days, as they aim at different levels of the socio-economic system. However, some address the micro, meso, and macro competitiveness phenomenon from a more integrated and systematic perspective. Table 5 presents this kind of systemic perspectives:

Table 5: Integrated micro-meso-macro perspectives

\begin{tabular}{|c|c|}
\hline $\begin{array}{l}\text { Meyer-Stamer } \\
(2005, \text { p. 3) }\end{array}$ & $\begin{array}{l}\text { The following levels describe the "basic structure of the System Competitiveness framework by } \\
\text { looking at key elements and policies at each of the four levels. ... Micro level includes technological, } \\
\text { organizational, and social innovations by efficient firms. ... Meso level includes targeted policies to } \\
\text { strengthen the competitiveness of certain sectors, such as industrial structure policies, importlexport } \\
\text { policies, regional policies, infrastructure policies, environmental policies, technology policies, } \\
\text { education policies, and labor policies... Macro level is about a stable macroeconomic, political and } \\
\text { judicial framework that includes competition policy, monetary policy, currency policy, budgetary } \\
\text { policy, fiscal policy, trade policy. ... Meta level is about the developmental orientation of society that } \\
\text { includes competitive pattern of economic organization, learning- and change-friendly value } \\
\text { attitudes, ability to formulate strategies and policies, collective memory, and social cohesion." }\end{array}$ \\
\hline $\begin{array}{l}\text { Voß and } \\
\text { Bornemann } \\
(2011)\end{array}$ & $\begin{array}{l}\text { "1. The micro level refers to a focal process of political interactions with a particular rule set (polity) } \\
\text { that structures interactions among participating individuals (politics) who deal with specific } \\
\text { problems and solutions (policy). }\end{array}$ \\
\hline
\end{tabular}




\begin{tabular}{|c|c|}
\hline & $\begin{array}{l}\text { 2. The meso level of politics includes patterns on the level of policy domains where comprehensive } \\
\text { policy programs are negotiated that frame whole issue areas. This takes place in the context of issue- } \\
\text { specific institutional arrangements (polity) that structure conflict and power struggle among } \\
\text { organized collectives with stakes in a particular issue (politics). } \\
\text { 3. The macro level captures broader patterns at the level of political systems that span a diversity of } \\
\text { issue areas. It entails discourses about fundamental values and forms of political organization } \\
\text { (policy), is structured by constitutional rules and basic cultural traditions (polity), and features } \\
\text { political struggle along broad social cleavages, societal sectors, or classes (politics)." }\end{array}$ \\
\hline $\begin{array}{l}\text { Mirzanti et al. } \\
(2015, \text { p. 399) }\end{array}$ & $\begin{array}{l}\text { "At the micro level, the policy is targeted to individual, which its contents are business skills, } \\
\text { opportunity identification skill, and psychological endowment including self motivated. At the meso } \\
\text { level, entrepreneur is defined as an organization that creates an added value through } \\
\text { entrepreneurial process with the content includes business incentives and administration burden. At } \\
\text { the macro level, the impact of entrepreneurship influences jobs creation and start-up creation } \\
\text { nationally in which the policy content includes entrepreneurship culture, entrepreneurship } \\
\text { infrastructure, and education." }\end{array}$ \\
\hline
\end{tabular}

The micro-meso-macro competitiveness policy is more of an overall system than a fragmented policy approach. This overall approach can be a "system of competitiveness" that takes into account all socio-economic development/underdevelopment characteristics. According to Meyer-Stamer (2005), at the broader level, at a "metalevel," there are usually tacit social processes that mold societal cohesion and the degree to which people are developmentally oriented. The micro-meso-macro system incorporates different political expressions and priorities at the three levels while, in particular, a micro-meso-macro entrepreneurship policy must understand how entrepreneurship systematically changes the socio-economic system as a whole.

The micro-meso-macro system could enable a complete understanding of policy levels. The distinction between micro and macro in the social sciences is only a conceptual distinction since systemic compositions always appear at different levels (Jepperson \& Meyer, 2011). Besides, the meso-economic environment dynamically unites the previously separate fields of microeconomics and macroeconomics (Zezza \& Llambí, 2002).

According to Dopfer et al. (2004, p. 264), this distinction between microeconomics and macroeconomics is mainly due to what the author calls as "algebraicism," in the sense that in economic science a scientific and philosophical understanding based solely on mathematical logic prevails: "The natural expression of algebraicism in economics is in the juxtaposition of formal microeconomic propositions in, necessarily, idealized static states with deduced macroeconomic consequences. Thus, economics involves a micro-macro division of analysis. Micro is individual choice, and macro is its aggregate consequences. The sum of micro is macro, and the decomposition of macro is micro."

In conclusion, it seems that scholars are trying to find out further the characteristics of this systemic synthesis between the three micro-meso-macro levels; that is, to understand the distinct - but at the same time co-evolving - approaches of each level individually and in their composition. The following section also undertakes and enriches this effort.

\section{An integrated approach of strengthening entrepreneurship and the competitiveness web}

Creating and implementing policies to stimulate competitiveness involves a multitude of factors that co-evolve dynamically. As a result, there is no definitive, well-implemented policy at all levels, applied in a static way to all socio-economic systems (Aranguren et al., 2017). It seems clear that such a policy must start from the "cellular" processes of the socio-economic system, which are at the level of the firm and its specific entrepreneurship.

According to Vlados (2004), the firms at the micro-level are "living" socio-economic systems; they are "organisms," which "inhale" and "exhale" socio-economic flows at three compound levels: in their spheres of strategy, technology, and management (Stra.Tech.Man approach). These "living organizations" have and express a particular "physiology" that defines their innovative potential. The three spheres of strategy, technology, and management that combine dynamic processes to compose innovation constitute the bonding substance of the specific "physiology" of the organization. Each socio-economic organization, whether explicitly or implicitly, strives to answer as effectively as possible three sets of strategic, technological, and managerial questions (Figure 1):

* Strategy explores the "Where am I, where am I going, how do I go there, and why?"

* Technology explores the "How do I draw, create, synthesize, spread, and reproduce the means of my work and know-how, and why?"

* Management explores the "How do I use my available resources, and why?" 
Figure 1: The Stra.Tech.Man approach of the socio-economic organization

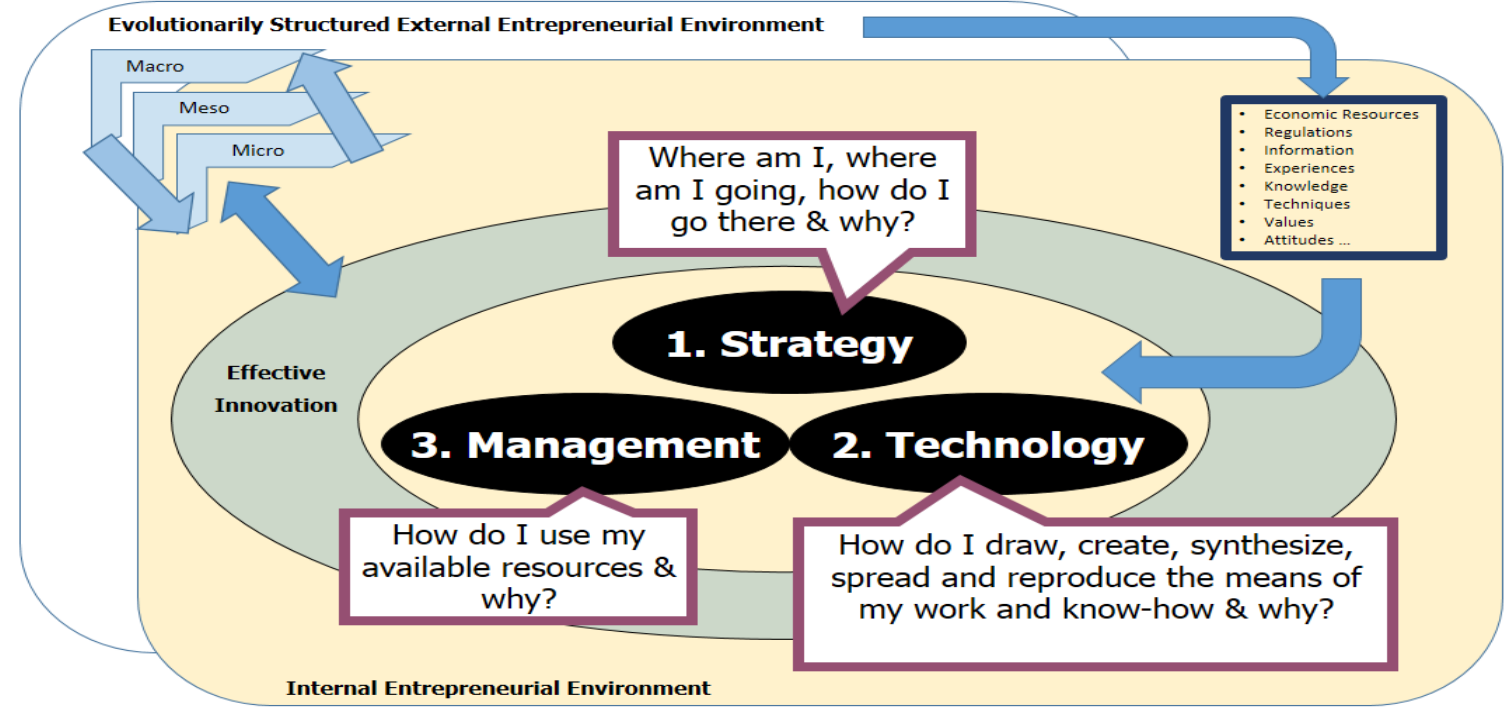

The socio-economic organization articulates its strategy, technology, and management to innovate. The shaping of innovation internally also affects the structuring of the external environment: the internal and external environments of the socio-economic organizations co-evolve (Breslin, 2016; Cantwell et al., 2010). In order to synthesize the innovative Stra.Tech.Man potential, the firm receives directly or indirectly elements and flows that transcend the economic sphere, such as knowledge, information, and any other relative social arrangement. These economic and social dimensions stem from the co-evolution of the internal and external environment at all possible micro-meso-macro levels (Gandellini et al., 2012; Vlados \& Chatzinikolaou, 2019b).

This "Stra.Tech.Man physiology" constitutes the "DNA" of the socio-economic organization as it enables it to survive and reproduce its innovative capacity (Vlados \& Chatzinikolaou, 2019a). In a "biological-type" view of socioeconomic development (Thomas, 1991; Witt, 2006), the "physiology" of the firm means that there are always specific strategic, technological, and managerial boundaries, beyond which there can be no "stretch" (Hamel \& Prahalad, 1993) at present. In this sense, the firms are different "animals" since they belong to different "species" that always allow only specific "openings" within the co-evolving business ecosystem that hosts them (Moore, 1993). In this perspective, the deeper qualitative Stra.Tech.Man characteristics are more significant than the size of the firm.

\section{Figure 2: The "competitiveness web" and the different levels of policies to strengthen entrepreneurship}

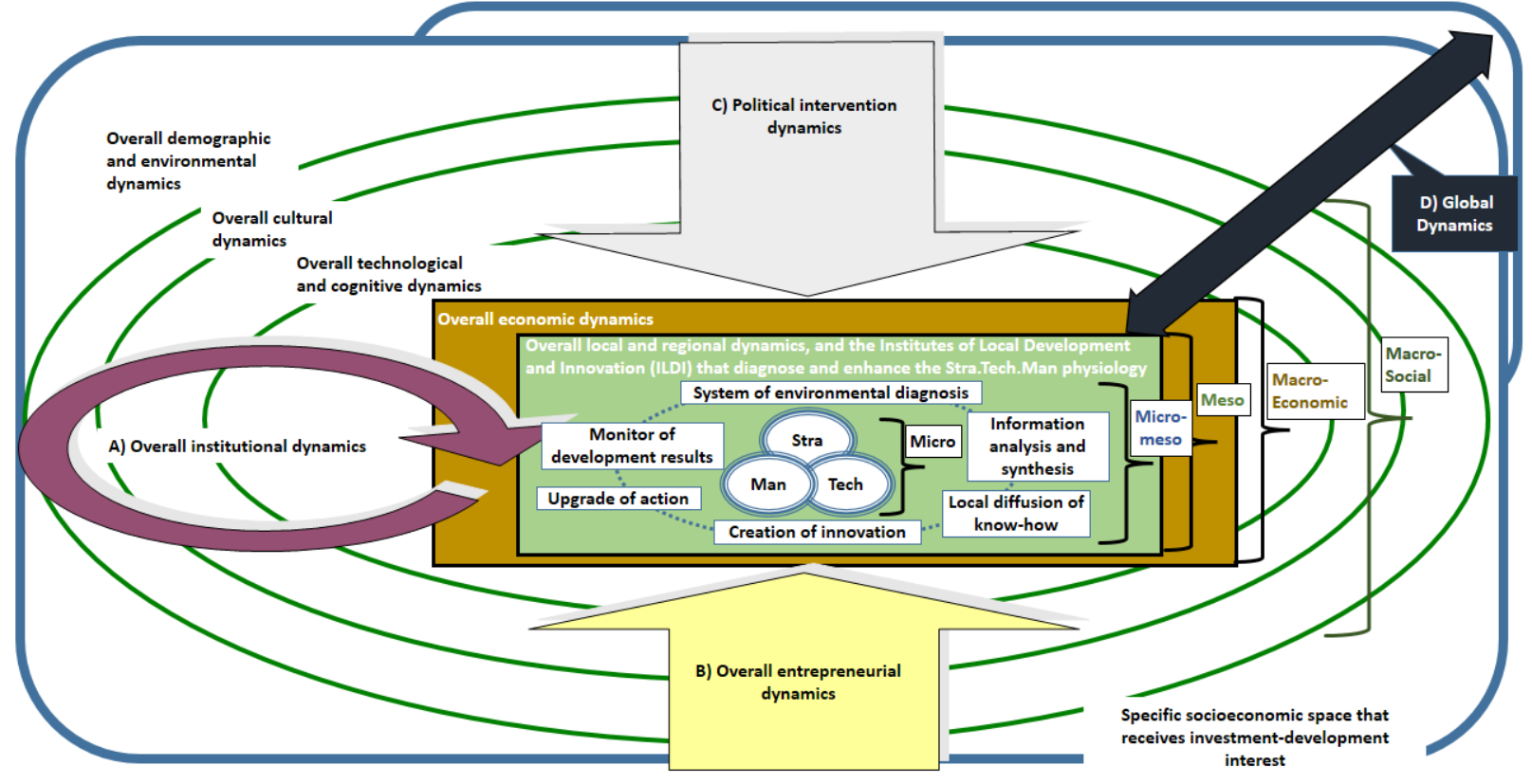


Thus, the firm and the entrepreneurship of its people (micro-level) change structurally the environment that hosts them (meso-macro-socioeconomic level). These systemic interactions between the different levels show that dynamic processes interconnect all the environments structurally. According to Vlados (2019a), the levels of space are a "competitiveness web" where a systemic interaction crosses the different sub-systems dynamically, from the broader macro-social subsystem to the micro-subsystem of the firm (Figure 2).

In the integrated system of "competitiveness web," the firms (micro), the sectors, and other business agglomerations and networks (meso), and the spaces that host this activity (macro) constitute a single entity, an "organism" that survives in today's competitive global environment. In this context, the "competitiveness web" clarifies what each level of analysis includes, as well as its respective political targeting:

* The micro-level encompasses the dynamics of the firm in terms of strategy, technology, and management and the particular innovation that the firm synthesizes by assimilating the elements of the existing available economic resources, regulations, and any other related flow.

* The meso-level includes the dynamics of locality and other spatial aggregations between firms (industries) and other development actors.

* The macroeconomic level encompasses the dynamics of the economy, recognized mainly from the growth or contraction of economic quantities, and includes financial-economic results at the aggregated level.

* The macro-social level includes all other social factors that shape the developmental perspectives of the system, such as the diffused technological and cognitive dynamics, the dynamics of the cultural environment, and the demographic-environmental pressures that overarch the other subsystems.

Moreover, the compositions of the spheres of entrepreneurial dynamics, political intervention, institutional capacity, and global dynamics that affect dynamically all subsystems that attract development interest (in the form of broadly conceived investment) transform these micro-meso-macro socio-economic levels structurally. Although the competitiveness web system integrates the different dimensions comprehensively, micro-meso-macro policies take on specific features and political targeting:

* At the micro-level, the policy aims to enhance the strategic, technological, and managerial potential of the firm, through research, education, and consulting, to the standards advocated by literature and policy at the micro-level (Bianchi, 2000; Fotopoulos \& Storey, 2019; OECD, 2007).

* At the micro-meso and meso levels, the policy includes a specific framework for strengthening localities in the form of "Local Development and Innovation Institutes" (ILDIs). The ILDI aims to connect local government, local-regional educational institutions, and local firms (Vlados \& Chatzinikolaou, 2019c) by targeting the strengthening of local entrepreneurship (Vlados, 2016). The ILDI accomplishes this by utilizing a cycle of six steps based on the diagnosis of the particular Stra.Tech.Man physiology of the firm and the locality in aggregate terms. These six steps begin with setting up an environmental diagnostics system, continuing with the analysis and synthesis of available information, followed by diffusing local expertise, creating innovation, and upgrading local entrepreneurship in terms of Stra.Tech.Man and, lastly, by monitoring and evaluating development results.

* At the macro-economic level, all reforms, usually derived from the country's Ministry of Finance, apply directly or indirectly to entrepreneurship. For example, these are reforms to the tax framework and policies of a similar horizontal reach. However, in a new type of government policy where relationships can be "vertical" and "diagonal" in addition to horizontal, other government authorities can contribute to the macroeconomic policy as well, such as with labor law, education and energy reforms, or similar "extra-economic" legislations.

* In this context, macro-social policies relate to all those policies external to the competence of the Ministry of Finance, concerning policymakers who regulate other aspects of social symbiosis. Besides, the developmental predisposition of the society to this dynamic system of competitiveness web, as well as the effects the society receives from subsystems, plays a decisive role in the system's prospects. This analysis also refers to the so-called business environment reforms (World Bank, 2019).

\section{Conclusions and discussion}

Can some of the micro-meso-macro policies be more significant for strengthening entrepreneurship than others? In an integrated approach to competitiveness policy, in the form of a competitiveness web, the center of gravity seems to lie predominantly in reinforcing the micro-meso levels.

In the current phase of restructuring of globalization, the issue of development seems to change the way socioeconomic sciences perceive socio-economic evolution (Vlados, Deniozos, Chatzinikolaou, et al., 2018). There seems to be a shift in the dominant interpretive paradigm (Kuhn, 1962) in the competitiveness strengthening conception from partial and non-cohesive policies - on either a macro, meso, or micro-level - to an integrated view of the dynamics that contribute to socio-economic development across all systems/subsystems. 
In this context, development/underdevelopment dynamics are multilevel, requiring a structural and "organic" understanding of the micro-meso-macro environments since socio-economic entities evolve today within a global socio-economic system. According to the converging perspective of Dopfer et al. (2004), the micro-meso-macro levels are above all evolutionary. More precisely, it is essential to understand that evolutionary microeconomics is about how socio-economic actors interact with a subset of other agents and that evolutionary meso-economics describes the core of structural change of the system, while evolutionary macroeconomics is how the overall "organization" transforms within a complex structure and associated processes.

Moreover, at the micro-firm level of strategy, technology, and management, the way the firms can manage the change as "living socio-economic organizations" is of critical importance (Vlados, 2019a). The competitiveness web approach helps to perceive that socio-economic development stems from the competitive potential of the firm that does not arise automatically and externally. Socio-economic development derives from the particular decisions and behavior at the micro-level, disseminated to the other subsystems by causing increased heterogeneity in today's globalization (Scherer et al., 2013).

In this context, a new economic policy of entrepreneurship and competitiveness empowerment must now focus on supporting the "cells" of the system. The proposed micro-meso-level mechanism of the Local Development and Innovation Institutes has precisely this role, namely the promotion of innovation and productive knowledge of local entrepreneurship at the local-regional level.

In conclusion, the central finding of this study is that the competitiveness web is a modern form of an integrated economic policy of competitiveness and entrepreneurship. The competitiveness web is a framework for recognizing the evolutionary constraints and perspectives that policymakers may face in today's world of rapid and profound restructuring of globalization.

\section{Acknowledgment}

We would like to express our gratitude to Dr. Andreas Andrikopoulos, Associate Professor at the Department of Business Administration of the University of the Aegean, who provided useful comments during the writing of this manuscript.

\section{References}

Acs, Z. J., Stam, E., Audretsch, D. B., \& O'Connor, A. (2017). The lineages of the entrepreneurial ecosystem approach. Small Business Economics, 49(1), 1-10. https://doi.org/10.1007/s11187-017-9864-8

Aghion, P., Alesina, A., \& Trebbi, F. (2007). Democracy, technology, and growth (Working Paper No. 13180). Cambridge, MA: National Bureau of Economic Research. https://doi.org/10.3386/w13180

Ahluwalia, M. S. (2015). Role of economists in policy-making (No. 144; WIDER Working Paper Series). Helsinki, Finland: World Institute for Development Economic Research (UNU-WIDER). https://doi.org/10.35188/UNU-WIDER/2015/033-1

Aiginger, K., Bärenthaler-Sieber, S., \& Vogel, J. (2013). Competitiveness under new perspectives (Working paper/WWWforEurope, WelfareWealthWork 44,). Vienna, Austria: WWWforEurope.

Andreou, A., Andrikopoulos, A., \& Nastopoulos, C. (2017). Chapter 1 - Debt markets, financial crises, and public finance in the Eurozone: Action, structure, and experience in Greece. In F. Economou, K. Gavriilidis, G. N. Gregoriou, \& V. Kallinterakis (Eds.), Handbook of Investors' Behavior During Financial Crises (pp. 3-28). London, UK: Academic Press. https://doi.org/10.1016/B978-0-12-811252-6.00001-3

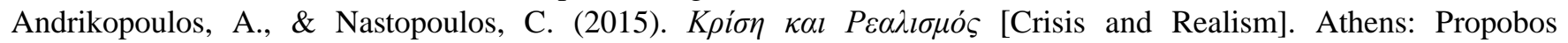
Publications.

Aranguren, M. J., Magro, E., \& Wilson, J. R. (2017). Regional competitiveness policy evaluation as a transformative process: From theory to practice. Environment and Planning C: Politics and Space, 35(4), 703-720. https://doi.org/10.1177/0263774X16662469

Atkinson, R. D. (2017). The competitive edge: A policymaker's guide to developing a national strategy (p. 67). Washington, DC: Information Technology \& Innovation Foundation.

Autio, E. (2016). Entrepreneurship support in Europe: Trends and challenges for EU policy [Report prepared for EU DG Growth]. Available at: https://doi.org/10.13140/RG.2.1.1857.1762 (accessed 5 December 2019).

Baldwin, R. E. (1969). The Case against Infant-Industry Tariff Protection. Journal of Political Economy, 77(3), 295305. https://doi.org/10.1086/259517

Berry, A., Culpeper, R., \& Stewart, F. (2016). Global development: Fifty years after Bretton Woods. London, UK: Palgrave Macmillan. 
Bianchi, P. (2000). Policies for Small and Medium-Sized Enterprises (SMEs). In W. Elsner \& J. Groenewegen (Eds.), Industrial Policies After 2000 (pp. 321-343). Dordrecht: Springer Netherlands. https://doi.org/10.1007/978-94011-3996-0_11

Breslin, D. (2016). What evolves in organizational co-evolution? Journal of Management \& Governance, 20(1), 45-67. https://doi.org/10.1007/s10997-014-9302-0

Bricongne, J.-C., Fontagné, L., Gaulier, G., Taglioni, D., \& Vicard, V. (2012). Firms and the global crisis: French exports in the turmoil. Journal of International Economics, 87(1), 134-146. https://doi.org/10.1016/j.jinteco.2011.07.002

Cantwell, J., Dunning, J. H., \& Lundan, S. M. (2010). An evolutionary approach to understanding international business activity: The co-evolution of MNEs and the institutional environment. Journal of International Business Studies, 41(4), 567-586. https://doi.org/10.1057/jibs.2009.95

Corrales-Leal, W. (2006). Revisiting competitiveness policies. Geneva, Switzerland: International Centre for Trade and Sustainable Development.

Danielsson, J. (2015). Macro vs microeconomic policy: Is there a winner? World Economic Forum. Available at: https://www.weforum.org/agenda/2015/10/macro-vs-microeconomic-policy-is-there-a-winner/ (accessed 5 December 2019).

Dijkstra, L., Gargano, N., Annoni, P., European Commission, \& Directorate-General for Regional and Urban Policy. (2017). The EU regional competitiveness index 2016. Luxembourg, Publications Office.

Dopfer, K. (2011). The origins of meso economics: Schumpeter's legacy and beyond. Journal of Evolutionary Economics, 22(1), 133-160. https://doi.org/10.1007/s00191-011-0218-4

Dopfer, K., Foster, J., \& Potts, J. (2004). Micro-meso-macro. Journal of Evolutionary Economics, 14(3), $263-279$. https://doi.org/10.1007/s00191-004-0193-0

Dutz, M. A., Ordover, J. A., \& Willig, R. D. (2000). Entrepreneurship, access policy and economic development: Lessons from industrial organization. European Economic Review, 44(4), $739-747$. https://doi.org/10.1016/S0014-2921(00)00030-1

European Commission. (2011). European Competitiveness Report 2011. Commission staff working document SEC(2011) 1188, Luxembourg: Office for Official Publications of the European Communities.

Fagerberg, J. (1988). International Competitiveness. The Economic Journal, 98(391), 355-374. https://doi.org/10.2307/2233372

Fotopoulos, G., \& Storey, D. J. (2019). Public policies to enhance regional entrepreneurship: Another programme failing to deliver? Small Business Economics, 53(1), 189-209. https://doi.org/10.1007/s11187-018-0021-9

Froy, F. (2013). Global policy developments towards industrial policy and skills: Skills for competitiveness and growth. Oxford Review of Economic Policy, 29(2), 344-360. https://doi.org/10.1093/oxrep/grt020

Gandellini, G., Pezzi, A., \& Venanzi, D. (2012). External and internal analysis of the environment. In G. Gandellini, A. Pezzi, \& D. Venanzi (Eds.), Strategy for Action - I: The Logic and Context of Strategic Management (pp. 4584). Milan, Italy: Springer Milan. https://doi.org/10.1007/978-88-470-2487-8_2

Gaudens-Omer, T. K. (2018). Public funds and entrepreneurship: A cognitive economics approach. Journal of Business \& Economic Policy, 5(2), 59-66. https://doi.org/10.30845/jbep.v5n2a9

Hamel, G., \& Prahalad, C. K. (1993). Strategy as stretch and leverage. Harvard Business Review, 71(2), 75-84.

Hartwell, C. A. (2014). Capital controls and the determinants of entrepreneurship. Czech Journal of Economics and Finance, 64(6), 434-456.

Hirschman, A. O. (1958). The strategy of economic development. New Haven, US; London, UK: Yale University Press.

Hoogduin, L., Öztürk, B., \& Wierts, P. (2011). Public debt managers' behaviour interactions with macro policies. Revue economique, Vol. 62(6), 1105-1122. https://doi.org/10.3917/reco.626.1105

IMD. (1994). The World Competitiveness Yearbook. Lausanne, Switzerland: IMD World Competitiveness Center (WCC).

Irwin, D. A. (2004). The aftermath of Hamilton's "Report on Manufactures." The Journal of Economic History, 64(3), 800-821. https://doi.org/10.1017/S0022050704002979

Ismail, H. I., \& Khalek, A. M. A. A. E. (2018). Intangible capital and its impacts on economic growth and competitiveness. Journal of Business \& Economic Policy, 5(2), 37-42. https://doi.org/10.30845/jbep.v5n2a6

Janger, J., Hölzl, W., Kaniovski, S., Kutsam, J., Peneder, M., Reinstaller, A., Sieber, S., Stadler, I., \& Unterlass, F. (2011). Structural change and the competitiveness of EU member states. Vienna, Austria: WIFO.

Jepperson, R., \& Meyer, J. W. (2011). Multiple levels of analysis and the limitations of methodological individualisms. Sociological Theory, 29(1), 54-73. https://doi.org/10.1111/j.1467-9558.2010.01387.x

Kao, L.-H., \& Hung, C.-Y. (2015). Anomalous financing choices with the change of industrial policy: The case of Taiwan. Journal of Business \& Economic Policy, 2(2), 132-143. 
Kappel, R., \& Ghani, E. (2003). Openness, institutions, and policies: Determinants of globalisation and economic growth in developing countries. The Pakistan Development Review, 42(4), 395-416. https://doi.org/10.30541/v42i4Ipp.395-416

Khattab, I., \& Al-Magli, O. O. (2017). Towards an integrated model of entrepreneurship ecosystem. Journal of Business \& Economic Policy, 4(4), 80-92.

Kim, M. (2019). A real driver of US-China trade conflict: The Sino-US competition for global hegemony and its implications for the future. International Trade, Politics and Development, 3(1), 30-40. https://doi.org/10.1108/ITPD-02-2019-003

Krugman, P. (1994). Competitiveness: A dangerous obsession. Foreign Affairs, 73(2), 28-44. https://doi.org/10.2307/20045917

Kuhn, T. S. (1962). The structure of scientific revolutions (3rd edition: 1996). Chicago, IL: University of Chicago Press.

Lall, S. (2004). Reinventing industrial strategy: The role of government policy in building industrial competitiveness (G-24 discussion papers No. 28). New York, NY: United Nations Conference on Trade and Development.

Levin, S. (2018). Mapping the meso space that enables technological change, productivity improvement and innovation in the manufacturing sector (working paper No. 3). Hatfield, Pretoria, South Africa: TIPS research report for Department of Trade and Industry.

Levitt, T. (1983). The globalization of markets. Harvard Business Review, 61(3), 92-102.

Link, A. (2007). Public policy and entrepreneurship. In D. Audretsch, I. Grilo, \& A. Thurik (Eds.), Handbook of Research on Entrepreneurship Policy (pp. 130-139). Cheltenham, UK; Northampton, MA, US: Edward Elgar.

Marra, A., Mazzocchitti, M., \& Sarra, A. (2018). Knowledge sharing and scientific cooperation in the design of research-based policies: The case of the circular economy. Journal of Cleaner Production, 194, 800-812. https://doi.org/10.1016/j.jclepro.2018.05.164

Meyer-Stamer, J. (2005). Systemic competitiveness revisited: Conclusions for technical assistance in private sector development (working paper No. 14). Duisburg, Germany: Mesopartner.

Mirzanti, I. R., Simatupang, T. M., \& Larso, D. (2015). Entrepreneurship policy implementation model in Indonesia. International Journal of Entrepreneurship and Small Business, 26(4), 399-415. https://doi.org/10.1504/IJESB.2015.072765

Moore, J. (1993). Predators and prey: A new ecology of competition. Harvard Business Review, 71(3), 75-86.

Naudé, W. (2010). Industrial policy: Old and new issues (Working Paper No. 106). Helsinki, Finland: World Institute for Development Economics Research.

OECD. (1995). Competitiveness policy: A new agenda. Paris, France: OECD Publishing.

OECD. (2005). Micro-policies for growth and productivity: Final report. Paris, France: OECD Publishing.

OECD. (2007). Micro-policies for growth and productivity Summary of key findings. Paris, France: OECD Publishing.

Ohmae, K. (1985). Triad power: The coming shape of global competition. New York, NY: The Free Press.

Pack, H. (2000). Industrial policy: Growth elixir or poison? The World Bank Research Observer, 15(1), 47-67. https://doi.org/10.1093/wbro/15.1.47

Peneder, M. (2017). Competitiveness and industrial policy: From rationalities of failure towards the ability to evolve. Cambridge Journal of Economics, 41(3), 829-858. https://doi.org/10.1093/cje/bew025

Perroux, F. (1969). L'économie du XXe siècle. Paris, France: Presses Universitaires de France.

Porter, M. (1990). The competitive advantage of nations New York, NY: Free Press. https://doi.org/10.1007/978-1-34911336-1

Rosenstein-Rodan, P. N. (1943). Problems of industrialisation of Eastern and South-Eastern Europe. The Economic Journal, 53(210/211), 202-211. https://doi.org/10.2307/2226317

Scherer, A. G., Palazzo, G., \& Seidl, D. (2013). Managing legitimacy in complex and heterogeneous environments: Sustainable development in a globalized world. Journal of Management Studies, 50(2), 259-284. https://doi.org/10.1111/joms.12014

Schultze, C. L. (1983). Industrial policy: A dissent. The Brookings Review, 2(1), 3-12.

Schwab, K. and Sala -i-Martín, X. (2017), The Global Competitiveness Report 2017-2018. Ottawa, CA: World Economic Forum.

Scott, B., \& Lodge, G. (Eds.). (1985). US competitiveness and the world economy. Boston, MA: Harvard Business School Press.

Sedelmeier, U. (2002). Sectoral dynamics of EU enlargement: Advocacy, access and alliances in a composite policy. Journal of European Public Policy, 9(4), 627-649. https://doi.org/10.1080/13501760210152466

Serpa, S., \& Ferreira, C. M. (2019). Micro, meso and macro levels of social analysis. International Journal of Social Science Studies, 7(3), 120-124. https://doi.org/10.11114/ijsss.v7i3.4223 
Shen, X. (1991). A strategic option for China: Development of an externally oriented economy—with a concomitant discussion of the "great international cycle." Chinese Economic Studies, 25(1), 34-48. https://doi.org/10.2753/CES1097-1475250134

Thomas, B. (1991). Alfred Marshall on economic biology. Review of Political Economy, 3(1), 1-14. https://doi.org/10.1080/09538259100000001

Timmer, C. P. (2000). The macro dimensions of food security: Economic growth, equitable distribution, and food price stability. Food Policy, 25(3), 283-295. https://doi.org/10.1016/S0306-9192(00)00007-5

Torfing, J., Peters, B. G., Pierre, J., \& Sørensen, E. (2012). Horizontal, vertical, and diagonal governance. New York, NY: Oxford University Press. https://doi.org/10.1093/acprof:oso/9780199596751.003.0006

Torjman, S. (2005). What is policy? Ottawa, Canada: Caledon Institute of Social Policy.

Vlados, Ch. (2004). La dynamique du triangle stratégie, technologie et management: L'insertion des entreprises grecques dans la globalisation. Paris, France: Thèse de doctorat de Sciences Économiques, Université de Paris $\mathrm{X}$-Nanterre.

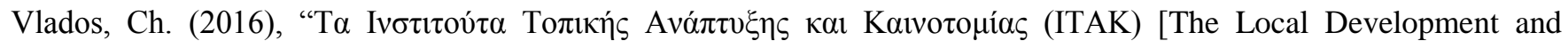

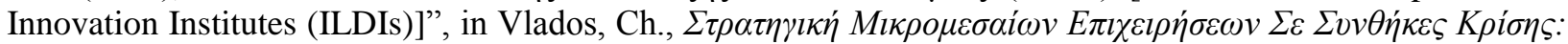

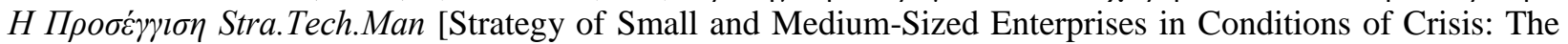
Stra.Tech.Man Approach] (pp. 516-520). Athens: Kritiki Publications.

Vlados, Ch. (2019a). Change management and innovation in the "living organization": The Stra.Tech.Man approach. Management Dynamics in the Knowledge Economy, 7(2), 229-256. https://doi.org/10.25019/MDKE/7.2.06

Vlados, Ch. (2019b). Porter's diamond approaches and the competitiveness web. International Journal of Business Administration, 10(5), 33-52. https://doi.org/10.5430/ijba.v10n5p33

Vlados, Ch. (2019c). The phases of the postwar evolution of capitalism: The transition from the current crisis into a new worldwide developmental trajectory. Perspectives on Global Development and Technology, 18(4), 457488. https://doi.org/10.1163/15691497-12341528

Vlados, Ch., \& Chatzinikolaou, D. (2019a). Business ecosystems policy in Stra.Tech.Man terms: The case of the Eastern Macedonia and Thrace region. Journal of Entrepreneurship, Management and Innovation, 15(3), 163197. https://doi.org/10.7341/20191536

Vlados, Ch., \& Chatzinikolaou, D. (2019b). Methodological redirections for an evolutionary approach of the external business environment. Journal of Management and Sustainability, 9(2), 25-46. https://doi.org/10.5539/jms.v9n2p25

Vlados, Ch., \& Chatzinikolaou, D. (2019c). Developments on helix theory: Exploring a micro-evolutionary repositioning in Stra.Tech.Man terms. International Journal of World Policy and Development Studies, 5(10), 87-99. https://doi.org/10.32861/ijwpds.510.87.99

Vlados, Ch., Deniozos, N., \& Chatzinikolaou, D. (2018). The possible paths of a new globalization. International Journal of Development and Sustainability, 7(9), 2310-2333. https://doi.org/10.5539/ibr.v11n8p9

Vlados, Ch., Deniozos, N., Chatzinikolaou, D., \& Demertzis, M. (2018). Towards an evolutionary understanding of the current global socio-economic crisis and restructuring: From a conjunctural to a structural and evolutionary perspective. Research in World Economy, 9(1), 15-33. https://doi.org/10.5430/rwe.v9n1p15

Voß, J.-P., \& Bornemann, B. (2011). The politics of reflexive governance: Challenges for designing adaptive management and transition management. Ecology and Society, 16(2), 9. https://doi.org/10.5751/ES-04051160209

Warwick, K. (2013). Beyond Industrial Policy: Emerging Issues and New Trends (OECD science, technology and industry policy papers No. 2). Paris, France: OECD Publishing. https://doi.org/10.1787/5k4869clw0xp-en

Wiley, N. (1988). The micro-macro problem in social theory. Sociological Theory, 6(2), 254-261. https://doi.org/10.2307/202119

Witt, U. (2006). Evolutionary concepts in economics and biology. Journal of Evolutionary Economics, 16(5), 473-476. https://doi.org/10.1007/s00191-006-0034-4

World Bank. (2019). Doing Business 2019: Training for reform. Washington, DC: World Bank.

World Economic Forum. (2000). Global Competitiveness Report 2000. New York, NY: Oxford University Press.

Zezza, A., \& Llambí, L. (2002). Meso-economic filters along the policy chain: Understanding the links between policy reforms and rural poverty in Latin America. World Development, 30(11), 1865-1884. https://doi.org/10.1016/S0305-750X(02)00113-4 